\title{
Genetic Diversity of Elaeagnus angustifolia L. (Elaeagnaceae) Populations in İzmir (Turkey)
}

\author{
Erengül SOFYALIOĞLU1 ${ }^{1}$, Emre SEVİNDİK ${ }^{1 *}$, Hüseyin UYSAL ${ }^{1}$
}

${ }^{1}$ Department of Agricultural Biotechnology, Faculty of Agriculture, Adnan Menderes University, South Campus, Cakmar, Aydin, Turkey

*Corresponding author: E. Sevindik e-mail: ph.d-emre@hotmail.com

RESEARCH ARTICLE

\begin{abstract}
This study was performed out genetic diversity of some Elaeagnus angustifolia L. populations growing in İzmir province by using ISSR markers. In the study, PCR was performed using 15 ISSR primers. PCR products were run in agarose gel and visualized under UV light. Amplified products were scored as follows. A total of 46 bands were produced from 15 ISSR primers, of which 27 were polymorphic. The proportion of polymorphic bands was evaluated as approximately 58.7\%. Genetic distances between phylogenetic trees and genotypes were calculated using the PAUP program. The phylogenetic tree consists of two large clades. The longest distance between populations was between Gümüldür-Özdere and Çeşme-Alaçatı population with a value of 0.50 , while the closest distance was between Çeşme-Ayayorgi and Konak-Hatay populations with a value of 0.06 . The results show that ISSR markers are useful tools for determining genetic relationships between E. angustifolia populations.
\end{abstract}

Keywords: Elaeagnus angustifolia; ISSR; genetic diversity; Turkey.

Received: 30 November 2020

Accepted: 04 April 2021

Published: 15 May 2021

DOI:

10.15835/buasvmcn-agr:2020.0048

2021 Authors. The papers published in this journal are licensed under the Creative Commons Attribution-NonCommercialNoDerivatives 4.0 International License

\section{INTRODUCTION}

Turkey has a variety of climates ranging from subtropical to cold-temperate. Due to these different conditions, the country has significant plant genetic diversity and there are many fruit tree taxa in the country (Uzun et al., 2015). The family of Elaeagnaceae has three genus as being Elaeagnus L., Hippophae L. and Shepherdia Nutt, and has 77 species worldwide (Khadivi, 2018; Asadiar et al., 2013; Sun and Lin, 2010). Also known as oleaster or Russian olive, Elaeagnus angustifolia L. belongs to the Elaeagnus genus of the Elaeagnaceae family (Carradori et al., 2020; Hamidpour et al., 2017). E. angustifolia is a fast-growing tree growing up to $10 \mathrm{~m}$ in height and a trunk diameter of up to $30 \mathrm{~cm}$ (Uzun et al., 2018) This species, known as oleaster, is found in the central and western regions of the Asian continent, in Gobi Desert, in the Alps, and around the Mediterranean; and it is present in all of the Black Sea, Marmara, South Anatolia and South East Anatolia regions of our country (Göktürk et al., 2007). In Turkey, E. angustifolia, whose cultivated form is called oleaster and the natural form is called Russian olive, grows naturally (Gülcü and Uysal, 2010). Fruit of E. angustifolia, which is an ornamental tree, have been used as a source of food and pharmaceutical industry (Yagmur et al., 2020; Karami and Piri, 2009). In addition, its fruits are rich in vitamins and minerals (potassium, sodium and phosphorus) such as tocopherol, terpenoids, tannins, amino acids, flavonoid, saponins, vitamin C, B1, glucose, fructose, and $\alpha$-carotene and are traditionally used in folk medicine as analgesic, in gastrointestinal system diseases, and for its antipyretic and diuretic activities 
(Khadivi et al., 2020; Carradori et al., 2020; Hassanzadeh and Hassanpour, 2018; Abizov et al., 2008). However, it is known that substances such as tea, animal feed, pulp and seed pulp are produced from its leaves, and jams and drinks are produced from its fruits (Şahin and Altuntaş, 2018). It has also been used to treat a variety of ailments such as nausea, vomiting, bloating, stomach ailments, asthma, and hepatitis (Incilay, 2014). Molecular marker physically corresponds to a location in the genome and plays an important role in diversity studies, germplasm characterization, phylogenetic analysis, linkage mapping (Mehri et al., 2020; Mukherjee et al., 2013; Behera et al., 2008). With the advent of molecular techniques, DNA-based procedures have been proposed for variety identification (Hu and Quiros, 1991). ISSR (Inter-simple sequence repeats) technique, is applicable to organisms from diverse genera and because of the large number of primers available for analyses, it provides good overall genome coverage (Andiego et al., 2019). This technique, has been successfully used in plant genetics for genome fingerprinting, genetic diversity, phylogenetic analysis, and molecular breeding in marker assisted selection (Doğan et al., 2016; Tang et al., 2015; Son et al., 2012). The aim of this study was to perform a genetic diversity using ISSR markers for some E. angustifolia populations grown in the İzmir city of Turkey.

\section{MATERIALS AND METHODS}

\section{Plant Materials, Genomic DNA Isolation and PCR}

Leaf samples belonging to 11 E. angustifolia populations used in this study were collected from different districts of İzmir province of our country (Figure 1).
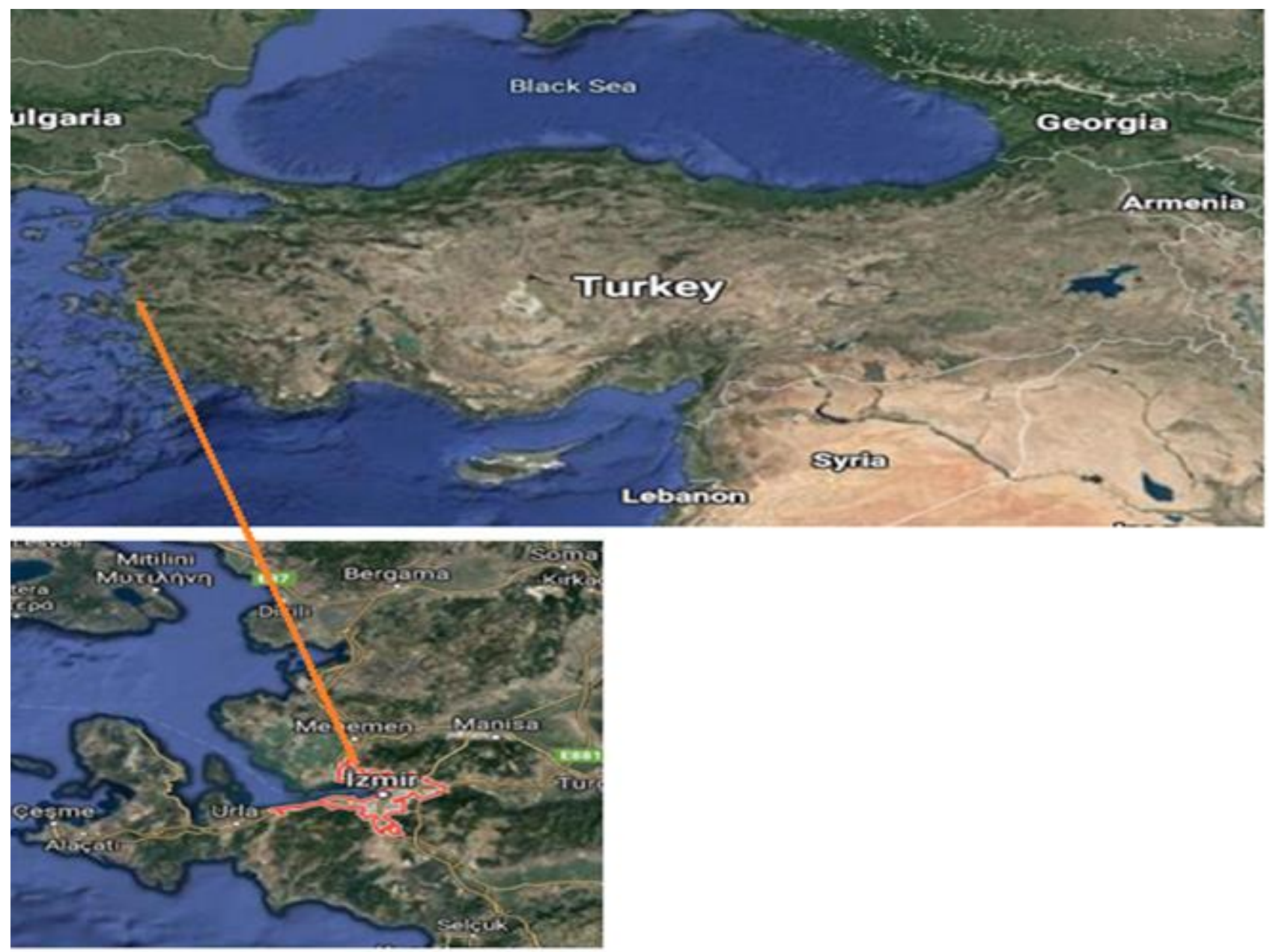

Figure 1. Location of the Izmir

(https.//www.google.com/maps_

Collected leaf samples were brought to the laboratory and prepared for genomic DNA isolation. Genomic DNA isolation was performed from plants using commercial kit (GeneMark, Cat No: DP022) as genomic DNA isolation method. The acquired gDNAs were stored at -20 degrees. PCR amplifications and selected ISSR primers for PCR amplifications are given in Table 1 and Table 2. 
Table 1. Primers used in the ISSR-PCR reactions and their Tm degrees

\begin{tabular}{|c|c|c|}
\hline Primers & DNA sequences $\left(5^{\prime}-3^{\prime}\right)$ & $\operatorname{Tm}^{\circ} \mathrm{C}$ \\
\hline UBC-855 & 5'-ACACACACACACACACYТ-3' & $52^{\circ} \mathrm{C}$ \\
\hline UBC-810 & 5' -GAGAGAGAGAGAGAGAT-3' & $50^{\circ} \mathrm{C}$ \\
\hline UBC-826 & 5'-ACACACACACACACCACC-3' & $52^{\circ} \mathrm{C}$ \\
\hline UBC-856 & 5'-ACACACACACACACACYA-3' & $52^{\circ} \mathrm{C}$ \\
\hline UBC-807 & 5'-AGAGAGAGAGAGAGAGT-3' & $50^{\circ} \mathrm{C}$ \\
\hline UBC-830 & 5’-TGTGTGTGTGTGTGTGG-3' & $52^{\circ} \mathrm{C}$ \\
\hline UBC-808 & 5'-AGAGAGAGAGAGAGAGC-3' & $52^{\circ} \mathrm{C}$ \\
\hline UBC-836 & 5'-AGAGAGAGAGAGAGAGYA-3' & $52^{\circ} \mathrm{C}$ \\
\hline UBC-853 & 5'-TCTCTCTCTCTCTCT CRT-3' & $52^{\circ} \mathrm{C}$ \\
\hline UBC-892 & 5'-TAGATCTGATATCTGAAT-3' & $52^{\circ} \mathrm{C}$ \\
\hline UBC-834 & 5'-AGAGAGAGAGAGAGAYT-3' & $52^{\circ} \mathrm{C}$ \\
\hline UBC-831 & 5'-СТСТСТстСТСТСТстT-3' & $50^{\circ} \mathrm{C}$ \\
\hline UBC-818 & 5'-CACACACACACACACAG-3' & $47^{\circ} \mathrm{C}$ \\
\hline UBC-811 & 5'-GAGAGAGAGAGAGAGAC-3' & $53^{\circ} \mathrm{C}$ \\
\hline UBC-873 & 5'- GACAGACAGACAGACA-3' & $48^{\circ} \mathrm{C}$ \\
\hline
\end{tabular}

Table 2. Cycles and conditions of ISSR-PCR reactions

\begin{tabular}{cccc}
\hline Pre-heating & $\mathbf{9 4}^{\circ} \mathrm{C}$ & $\mathbf{4} \mathbf{~ m i n}$ & $\mathbf{1 ~ c y c l e}$ \\
\hline 1. step & $94^{\circ} \mathrm{C}$ & $1 \mathrm{~min}$ \\
2. step & $47-53^{\circ} \mathrm{C}$ & $1 \mathrm{~min}$ & \\
3. step & $72^{\circ} \mathrm{C}$ & $1 \mathrm{~min}$ & 35 cycles \\
4. step & $72^{\circ} \mathrm{C}$ & $10 \mathrm{~min}$ & \\
5. step & $4^{\circ} \mathrm{C}$ & $20 \mathrm{~min}$ & 1 cycle \\
\hline
\end{tabular}

ISSR amplification reactions were carried out in $25 \mu \mathrm{L}$ volumes containing $5 \mu \mathrm{L}$ master mix (PCR buffer, MgCl2, dNTPs, Taq DNA polymerase), $1 \mu \mathrm{L}$ ISSR primers, $2 \mu \mathrm{L}$ of total genomic DNA, and $17 \mu \mathrm{L}$ of sterilized dH2O. 1,5\% agarose gel TBE buffer was used for electrophoresis of PCR products. For the gel; 1,5 g agarose and 100 ml 1X TBE were combined and melted in microwave for $1 \mathrm{~min}$. After the mixture was removed from the microwave, Ethidium Bromide $(0.1 \mu \mathrm{g} / \mathrm{ml})$ was added as dye and poured into the gel preparation plate of the horizontal type electrophoresis device. $5 \mu \mathrm{l}$ of the reaction mixture in PCR tubes was added to $1 \mu$ l loading buffer (Loading Dye Solution) and mixed and $6 \mu \mathrm{l}$ of this mixture was placed in the wells in the gel. After loading a 3 kb DNA marker into the first well, the device was subjected to electrophoresis at $90 \mathrm{~V}$ for 90 minutes. Then, the DNA bands were imaged under UV light and their photos were taken. Some gel picture of ISSR marker region shown in Figure 2.

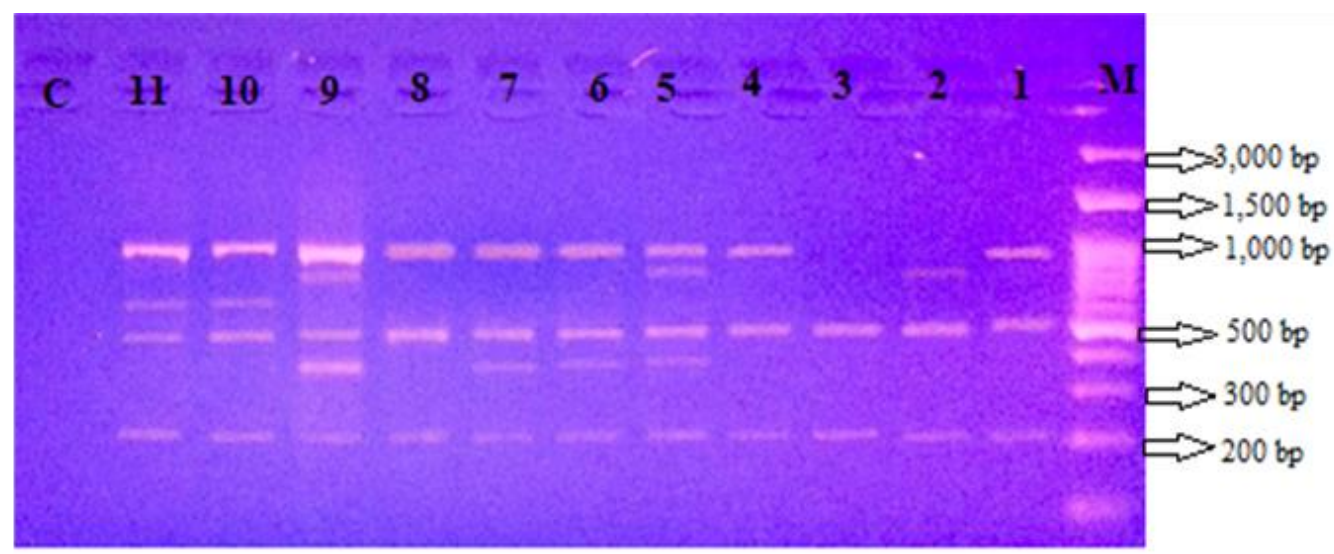

Figure 2. Gel image of ISSR-PCR band amplified with UBC-811 


\section{ISSR Analysis}

After the PCR analyses, DNA bands were scored as follows: " 1 " was given if there is DNA in the DNA bands, "0" was given if there is no DNA, and "?" was given for missing data; and monomorphic bands were discarded and ISSR analyses were performed on polymorphic bands. Genetic relationship of E. angustifolia populations used in the study was analyzed using the PAUP 4.0b10 (Swofford, 2001) program, and genetic matrix between populations was revealed by drawing UPGMA phylogenetic tree of the same program according to the arithmetic means of the pedigree trees.

\section{RESULTS AND DISCUSSIONS}

Genetic diversity is the key to plant breeding programs, general measured by genetic distance or genetic similarity (Behera et al., 2008; Fu et al., 2008). DNA markers provide an opportunity to measure genetic relationships between genotypes (Souframanien and Gopalakrishna, 2004). ISSR markers are a simple, efficient and repeatable marker system with high polymorphism, this marker is useful for fingerprinting, mapping, and taxonomic and phylogenetic analysis (Souza et al., 2017; Gürcan and Mehlenbacher, 2010).

In the study, 15 ISSR primers were used and a total of 46 bands were obtained. Of these bands, 19 were monomorphic and 27 were polymorphic. The rate of polymorphism is approximately $58.7 \%$. The UPGMA phylogenetic tree, consists of two major clades. Clade 1 divide into two subclades. Subclades A, consists of Seferihisar- Sığacık, Urla Demircili village, Çeşme- Ayayorgi, Konak-Hatay, Urla-Zeytinalanı. Subclade B consists of Bornova-Çamdibi, Gümüldür-Özdere and Mordoğan populations. Clade 2, consists of Çeşme-Alaçatı, Urla-Kuşçular and Balçova populations (Figure 3).

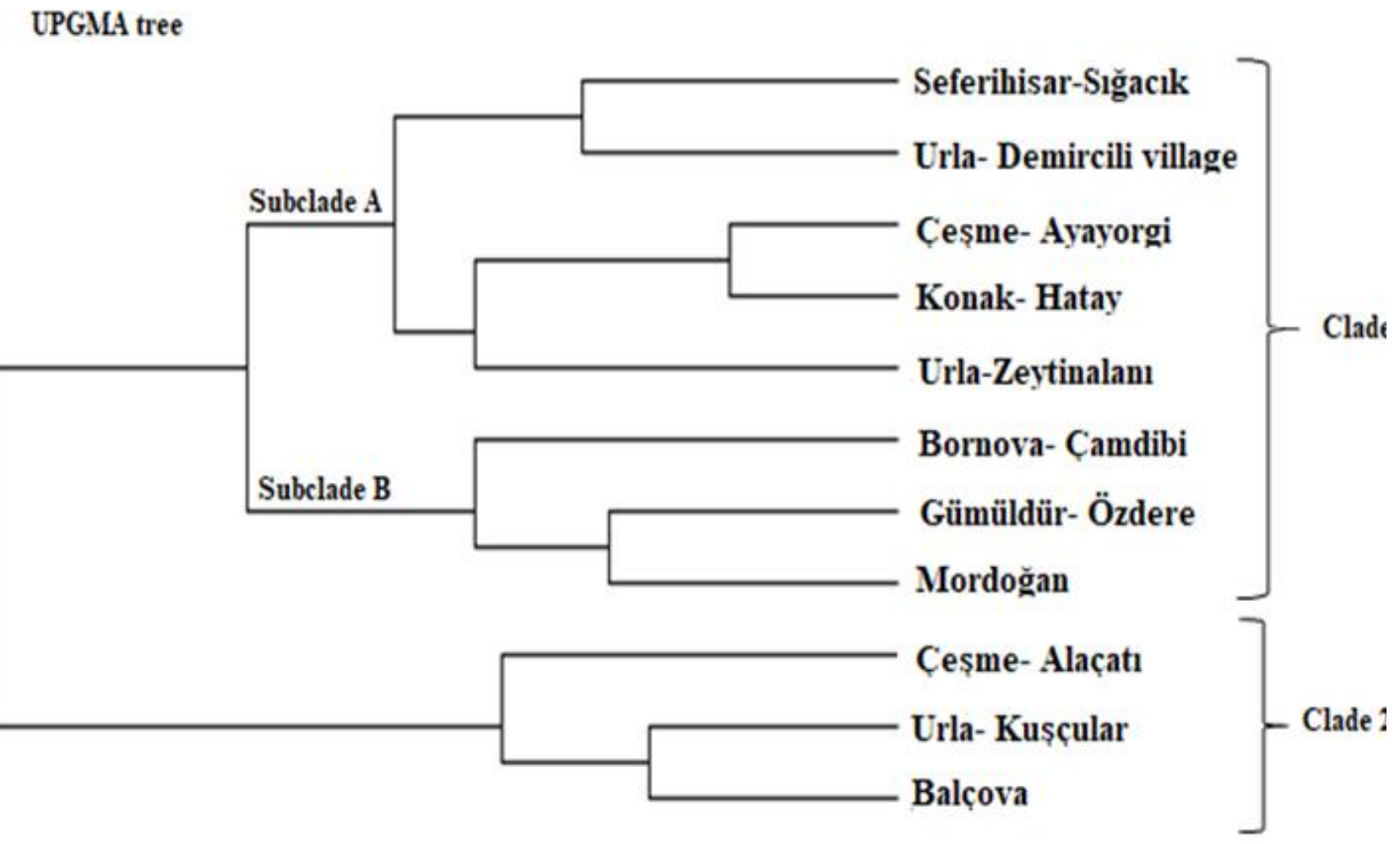

Figure 3. The UPGMA tree generated using ISSR data of

Elaeagnus angustifolia populations

The longest distance between populations was between Gümüldür-Özdere and Çeşme-Alaçatı population with a value of 0.50 , while the closest distance was between Çeşme-Ayayorgi and Konak-Hatay populations with a value of 0.06. (Table 3). 
Table 3. Pairwise genetic distance matrix obtained from PCR with ISSR primers

\begin{tabular}{llllllllllll}
\hline Populations & $\mathbf{1}$ & $\mathbf{2}$ & $\mathbf{3}$ & $\mathbf{4}$ & $\mathbf{5}$ & $\mathbf{6}$ & $\mathbf{7}$ & $\mathbf{8}$ & $\mathbf{9}$ & $\mathbf{1 0}$ & $\mathbf{1 1}$ \\
\hline Seferihisar-Sı̆̆acık (1) & - & 0.17 & 0.13 & 0.12 & 0.27 & 0.22 & 0.32 & 0.32 & 0.45 & 0.41 & 0.27 \\
Çeşme- Ayayorgi (2) & 6 & - & 0.06 & 0.23 & 0.17 & 0.15 & 0.35 & 0.29 & 0.33 & 0.38 & 0.30 \\
Konak- Hatay (3) & 4 & 2 & - & 0.20 & 0.20 & 0.17 & 0.30 & 0.23 & 0.38 & 0.33 & 0.26 \\
\hline Urla- Demircili village (4) & 5 & 8 & 6 & - & 0.18 & 0.25 & 0.27 & 0.20 & 0.46 & 0.35 & 0.27 \\
Bornova- Çamdibi (5) & 11 & 6 & 6 & 8 & - & 0.20 & 0.18 & 0.15 & 0.34 & 0.39 & 0.33 \\
\hline Urla-Zeytinalanı (6) & 8 & 5 & 5 & 10 & 8 & - & 0.35 & 0.27 & 0.30 & 0.30 & 0.34 \\
Gümüldür- Özdere (7) & 13 & 12 & 9 & 12 & 8 & 14 & - & 0.11 & 0.50 & 0.46 & 0.42 \\
\hline Mordoğan (8) & 13 & 10 & 7 & 9 & 7 & 11 & 5 & - & 0.46 & 0.35 & 0.33 \\
Çeșme- Alaçatı (9) & 10 & 6 & 7 & 12 & 9 & 8 & 13 & 12 & - & 0.14 & 0.17 \\
\hline Urla- Kuşçular (10) & 10 & 7 & 6 & 10 & 11 & 8 & 13 & 10 & 4 & - & 0.10 \\
\hline Balçova (11) & 8 & 7 & 6 & 9 & 11 & 10 & 14 & 11 & 5 & 3 & - \\
\hline
\end{tabular}

In previous studies, Uzun et al. (2015) determined the genetic variation of 56 E. angustifolia populations from various districts and altitudes of Kayseri province, located in Central Anatolia region of Turkey, by using RAPD and ISSR markers. They used seven RAPD and fifteen ISSR primers in their study and obtained 74 bands for RAPD analysis and 135 bands for ISSR analysis. In the RAPD results, 67 polymorphic bands were obtained, the polymorphism rate was approximately $90 \%$; and 115 polymorphic bands were obtained in ISSR results, and they determined the polymorphism rate as approximately $85 \%$. By combining RAPD and ISSR data, they determined the genetic distance between the populations between 0.34 and 0.00. Uzun et al., (2018) determined the molecular characterization of 25 E. angustifolia populations, collected from Nevşehir, Aksaray, Konya, Sivas, Malatya, Adıyaman and Kahramanmaraş provinces of Turkey, by using the ISSR marker system. In their study, they produced a total of 92 fragments from 11 ISSR primers and revealed that 23 of them were polymorphic and the rate of polymorphism was $25 \%$. They found through the UPGMA analysis that the similarity index was between 0.63 and 1.00. Talebi-Rad et al., (2015) determined the genetic diversity of E. angustifolia populations from five different points of the Eastern Azarbeycan state of Iran through RAPD markers. In their study, they identified a total of 29 polymorphic bands ranging from 100 to $1500 \mathrm{bp}$. They found the rate of polymorphism as approximately $97.22 \%$. In their study results, they revealed that RAPD analysis showed that it is an appropriate method to examine genetic diversity and relationships between E. angustifolia populations. Asadiar et al., (2012) determined the genetic variation of E. angustifolia populations collected from nine different locations in the West Azarbeycan province of Iran through RAPD markers. In their study, they used nine RAPD primers and obtained a total of 122 bands. A total of 103 of these bands were polymorphic, and they determined the polymorphism rate as approximately $84.4 \%$. Also, the estimated Jaccard's similarity index ranged from 0.36 to 0.62 for the RAPD marker. As a result of their studies, they revealed that the RAPD marker is a useful tool for evaluating genetic diversity within the Elaeagnus genus. Asadiar et al. (2013) determined the genetic relationship and polymorphism levels of nine E. angustifolia populations collected from nine different locations in the West Azarbeycan province of Iran through ISSR markers. In their study, they used 11 ISSR primers and obtained 116 bands. 92 of these bands were polymorphic and the rate of polymorphism was determined as approximately $79.3 \%$. The estimated Jaccard's similarity index ranged from 0.44 to 0.76 for the ISSR marker. As a result of the study, they revealed that it can be concluded that ISSR markers are suitable tools for evaluating genetic diversity and relationships within the Elaeagnus genus. Yingthongchai et al., (2014) determined the genetic diversity and phylogenetic analysis of 88 E. latifolia populations collected from the North of Thailand through the ISSR marker system. 14 selected primers were used in the study, 278 bands were obtained in total and 264 of these bands were found to be polymorphic. The rate of polymorphism in their work was determined to be approximately $94.96 \%$. They also found that Jaccard's similarity index or genetic similarity (G-Sj) ranged from 0.50-0.79. In their study, they revealed that the ISSR marker system can be used to distinguish the relationship between E. latifolia populations and to evaluate the genetic relationship.

\section{CONCLUSIONS}

This study has revealed genetic diversity of E. angustifolia populations distributed in İzmir city of Turkey by using ISSR technique. Approximately 58.7 \% polymorphism was detected among E. angustifolia ISSR analysis. As a result, the outcomes of the research, which aimed to analyze the genetic diversity of $E$. angustifolia populations in different localities through ISSR molecular marker, will be used in the development of more efficient new varieties, particularly for breeding, through the association with many different specific characters of $E$. angustifolia populations 
Author Contributions: E.S. Collecting plant samples. ES, E.S and H.U. experimental studies and data analysis. E.S. Wrote the paper and conceived and designed the analysis.

\section{Acknowledgements}

This research was supported by the TUBİTAK 2019/2209-A (Project no: 1919B011901071)

\section{Conflicts of Interest}

The authors have no conflict of interest to declare

\section{REFERENCES}

1. Abizov EA, Tolkachev ON, Mal'Tsev SD, Abizova EV (2008). Composition of biologically active substances isolated from the fruits of Russian olive (Elaeagnus angustifolia) introduced in the European part of Russia. Pharm Chem J.; 42(12): 696-698.

2. Andiego KP, Dangasuk OG, Odee DW, Omondi FS, Otieno DF, Balozi BK (2019). Genetic diversity of endangered sandalwood (Osyris lanceolata) populations in Kenya using ISSR molecular markers. East African Agricultural and Forestry Journal. 83(2): 80-93.

3. Asadiar LS, Rahmani F, Siami A (2012). Assessment of genetic variation in Russian olive (Elaeagnus angustifolia) based on morphological traits and random amplified polymorphic DNA (RAPD) genetic markers. J Med Plant Res. 6(9): 1652-1661.

4. Asadiar LS, Rahmani F, Siami A (2013). Assessment of genetic diversity in the Russian olive (Elaeagnus angustifolia) based on ISSR genetic markers. Rev Ciênc Agron. 44(2): 310-316.

5. Behera TK, Gaikward AB, Singh AK, Staub JE (2008). Relative efficiency of DNA markers (RAPD, ISSR and AFLP) in detecting genetic diversity of bitter gourd (Momordica charantia L.). J Sci Food Agric. 88(4): 733-737.

6. Carradori S, Cairone F, Garzoli S, Fabrizi G, Iazzetti A, Giusti AM, Cesa S (2020). Phytocomplex Characterization and Biological Evaluation of Powdered Fruits and Leaves from Elaeagnus angustifolia. Molecules. 25(9): 2021.

7. Doğan B, Çelik M, Ünal M, Sefali A, Martin E, Kaya A (2016). Study of phylogenetic relationship of Turkish species of Matthiola (Brassicaceae) based on ISSR amplification. Turk J Bot. 40(2): 130-136.

8. Göktürk A, Ölmez Z, Temel F, Yahyaoğlu Z (2007). Effects of Some Pre-Treatments on Germination of Russian Olıve (Elaeagnus angustifolia L.) Seeds. Süleyman Demirel Üniversitesi Orman Fakültesi Dergisi. 2: 32-41.

9. Gülcü S, Uysal SÇ (2010). Kuş İğdesi'nde (Elaeagnus angustifolia L.) Yetiştirme Sıklığının Fidan Morfolojik Özelliklerine Etkisi. Türkiye Ormancılık Dergisi. 11(2): 74-81.

10. Gürcan K, Mehlenbacher SA (2010). Development of microsatellite marker loci for European hazelnut (Corylus avellana L.) from ISSR fragments. Mol Breeding. 26(3): 551-559.

11. Fu X, Ning G, Gao L, Bao M (2008). Genetic diversity of Dianthus accessions as assessed using two molecular marker systems (SRAPs and ISSRs) and morphological traits. Sci Hortic. 117(3): 263-270.

12. Hamidpour R, Hamidpour S, Hamidpour M, Shahlari M, Sohraby M, Shahlari N, Hamidpour R (2017). Russian olive (Elaeagnus angustifolia L.): From a variety of traditional medicinal applications to its novel roles as active antioxidant, anti-inflammatory, anti-mutagenic and analgesic agent. JTCM. 7(1): 24-29.

13. Hassanzadeh Z, Hassanpour H (2018). Evaluation of physicochemical characteristics and antioxidant properties of Elaeagnus angustifolia L. Sci Hortic. 238: 83-90.

14. Hu J, Quiros CF (1991). Identification of broccoli and cauliflower cultivars with RAPD markers. Plant Cell Rep. 10(10): 505-511.

15. Incilay G (2014). Volatile Composition, Antimicrobial and Antioxidant Properties of Different Parts from Elaeagnus angustifolia L. J Essent Oil-Bear Plants. 17(6): 1187-1202.

16. Karami O, Piri K (2008). Shoot organogenesis in oleaster (Elaeagnus angustifolia L.). Afr J Biotechnol. 8(3): 438440.

17. Khadivi A (2018). Phenotypic characterization of Elaeagnus angustifolia using multivariate analysis. Ind Crop Prod. 120: 155-161.

18. Khadivi A, Mirheidari F, Moradi Y, Paryan S (2020). Phenotypic variability of oleaster (Elaeagnus angustifolia L.) as revealed by morphological characteristics. Ind Crop Prod. 149: 112322.

19. Mehri S, Ajirlou HS, Kolbadi I (2020). Evaluation of genetic diversity and morphological variability in Stellaria media (L.) Vill. using RAPD marker. Bangladesh J Plant Taxon. 27(1): 173-184.

20. Mukherjee A, Sikdar B, Ghosh B, Banerjee A, Ghosh E, Bhattacharya M, Roy, SC (2013). RAPD and ISSR analysis of some economically important species, varieties, and cultivars of the genus Allium (Alliaceae). Turk J Bot. 37(4): 605-618.

21. Son JH, Park KC, Lee SI, Kim JH, Kim NS (2012). Species relationships among Allium species by ISSR analysis. Hortic Environ Biotechnol. 53(3): 256-262. 
22. Souza CPF, Ferreira CF, de Souza EH, Neto ARS, Marconcini, J. M, da Silva Ledo CA, Souza FVD (2017). Genetic diversity and ISSR marker association with the quality of pineapple fiber for use in industry. Ind Crop Prod. 104: 263-268.

23. Souframanien J, Gopalakrishna T (2004). A comparative analysis of genetic diversity in blackgram genotypes using RAPD and ISSR markers. Theor Appl Genet. 109(8): 1687-1693.

24. Sun M, Lin Q (2010). A revision of Elaeagnus L. (Elaeagnaceae) in mainland China. J Syst Evol. 48(5): 356-390.

25. Swofford DL (2001). PAUP. phylogenetic analysis using parsimony (and other methods), version $4.0 \mathrm{~b} 10$. Sinaeur Associates, Sunderland.

26. Şahin G, Altuntaş E (2018). Kuş İğdesi Meyvesinin Fiziko-mekanik, Renk ve Kimyasal Özellikleri. GBAD. 7(1): $1-11$.

27. Tang WX, Dai WJ, Hu XH, Huang SX (2015). ISSR-based genetic diversity of wild and ex situ conserved population of Hopea chinensis (Merr.) Hand.-Mazz. Bangladesh J Bot. 44(3): 407-413.

28. Talebi-Rad H, Onsori H, Akrami S (2015). Genetic diversity among Elaeagnus angustifolia L. populations based on some morphological traits and Random Amplified Polymorphic DNA Markers. IJGPB. 4(1): 17-24.

29. Uzun A, Yıgit MA, Pinar H, Yaman M, Arslan S (2018). Molecular characterization of Elaeagnus angustifolia L. genotypes collected from different parts of Turkey. IJANS. 1(1): 10-13.

30. Uzun A, Celik B, Karadeniz T, Yılmaz KU, Altıntaş C (2015). Assessment of fruit characteristics and genetic variation among naturally growingwild fruit Elaeagnus angustifolia accessions. Turk J Agric For. 39(2): 286294.

31. Yagmur E, Gokce Y, Tekin S, Semerci NI, Aktas Z (2020). Characteristics and comparison of activated carbons prepared from oleaster (Elaeagnus angustifolia L.) fruit using KOH and ZnCl2. Fuel. 267: 117232.

32. Yingthongchai P, Naphrom D, Smitamana P (2014). Assessment of genetic diversity in Elaeagnus latifolia L. by Inter-Simple Sequence Repeat (ISSR) markers. IJAT. 10(3): 791-802. 